\title{
EVALUASI FENOTIPE QTL YANG TERSEGREGASI TRANSGRESIF PADA VARIETAS PADI NASIONAL DAN LOKAL DI LINGKUNGAN SAWAH BARU
}

\author{
Risky Ramadhana
}

\author{
Jurusan Agroteknologi, Fakultas Pertanian Universitas Lampung \\ Jl. Prof. Soemantri Brodjonegoro, No. 1, Bandar Lampung 35145 \\ E-mail: riskyramadhana@yahoo.co.id
}

\begin{abstract}
ABSTRAK
Penelitian ini bertujuan untuk mendapatkan QTL yang muncul pada varietas padi nasional dan lokal di lingkungan sawah baru, untuk mendapatkan peubah yang memiliki ragam genetik dan heritabilitas broad-sense pada padi nasional dan lokal; serta untuk mendapatkan peubah yang dapat digunakan sebagai seleksi tidak langsung pada padi nasional dan lokal. Penelitian ini disusun berdasarkan RKTS (Rancangan Kelompok Teracak Sempurna) dimana masing-masing kelompok diambil 9 sampel tanaman yang dibagi menjadi 3 ulangan dan masing-masing ulangan 3 tanaman. Data pada masing-masing peubah diuji Bartlett dan Levene untuk kehomogenan ragam sebelum di analisis ragam. Bila uji $\mathrm{F}$ pada analisis ragam berbeda $\mathrm{P} \leq 0.05$ atau 0.01 dilakukan pemeringkatan varietas padi berdasarkan $\mathrm{BNJ}_{0.05}$. Besarnya ragam genetik dan heritabilitas broad-sense diduga berdasarkan nilai kuadrat nilai tengah harapan pada hasil analisis ragam. Hasil penelitian menunjukkan bahwa QTL pada tanaman padi muncul pada varietas nasional dan lokal di lingkungan sawah baru, yaitu QTL sudut anakan, QTL tinggi tanaman dan QTL jumlah bulir. Semua peubah yang diamati mampu memberikan perbedaan ragam genetik dan heritabilitas broad-sense, tetapi untuk varietas peubah bobot gabah total tidak memberikan perbedaan, begitu juga untuk QTL peubah jumlah anakan total dan bobot gabah total yang tidak memberikan perbedaan ragam genetik dan heritabilitas broad-sense. Peubah yang dapat dijadikan seleksi tidak langsung adalah jumlah gabah isi.
\end{abstract}

Kata kunci: padi, segregasi transgresif, quantitative trait loci, seleksi tidak langsung.

\section{PENDAHULUAN}

Padi merupakan tanaman pangan yang memiliki arti ekonomi penting. Indonesia merupakan negara penghasil beras terbesar ketiga dunia setelah China dan India, namun produksi nasional belum mampu mencukupi kebutuhan domestik sehingga masih perlu mengimpor beras dari negara lain. Peningkatan produktivitas padi menjadi konsentrasi para pemulia tanaman untuk menjaga ketahanan pangan nasional (Nafisah $d k k, 2008$ )

Salah satu cara untuk meningkatkan produktivitas padi adalah dengan cara menggunakan padi hibrida. Penelitian yang dilakukan di International Rice Research Institute (IRRI) mulai tahun 1986 sampai 1995 menunjukkan padi hibrida memberikan peningkatan hasil sebesar $17 \%$ dibandingkan varietas inbrida. Sejumlah hibrida yang menunjukkan daya hasil lebih tinggi dibandingkan varietas padi inbrida juga telah dilepas sebagai varietas unggul nasional di Indonesia. Usaha untuk meningkatkan produksi padi dengan hibrida sangat sulit dilakukan karena kebiasaan petani yang menanam padi dua kali tanam dalam setahun maka mustahil menyediakan benih hibrida untuk setiap kali tanam (Hikam, 2011 dalam Suprayogi, 2011). Untuk mengatasi hal tersebut, diperlukan suatu alternatif berupa analisis Quantitative Trait Loci (QTL) merupakan bagian kromosom atau peta genetik yang terkait secara statistik dengan suatu variasi yang ditunjukkan oleh suatu sifat kuantitatif. Penentuan QTL ditentukan melalui suatu studi asosiasi antara variasi genotipe yang ditunjukkan oleh sejumlah penanda pada peta genetik dan variasi fenotipe yang terukur (Wikipedia, 2011).

Analisis QTL dapat membuktikan gen yang berperan didalam segregasi transgresif. Segregasi transgresif didefinisikan sebagai tampilan zuriat "self" yang jauh lebih baik daripada kedua tetuanya. Padi segregan transgresif memiliki beberapa keunggulan diantaranya berumur cepat, jumlah bulir yang banyak, tahan terhadap tanah podsolik merah kuning, dan tahan terhadap hama dan penyakit endemik seperti blas Pyricularia dan hawar daun Xanthomonas (Hikam, 2011 dalam Suprayogi, 2011).

Tujuan dari penelitian ini adalah mendapatkan QTL yang muncul pada varietas padi nasional dan lokal di lingkungan sawah baru, untuk mendapatkan peubah yang memiliki ragam genetik dan heritabilitas broadsense pada padi nasional dan lokal, serta untuk mendapatkan peubah yang dapat digunakan sebagai seleksi tidak langsung pada padi nasional dan lokal. 


\section{BAHAN DAN METODE}

Penelitian ini dilaksanakan di Politeknik Negeri Lampung, Rajabasa, Bandar Lampung dan Laboratorium Benih Universitas Lampung, Bandar Lampung dari bulan Februari sampai Juli 2012. Alat-alat yang digunakan dalam penelitian ini yaitu ajir bambu 1,5 m, meteran, kantung kertas, plastik, gunting, cutter, penggaris, pensil, timbangan, seed blower, oven, kamera digital, kuas dan cat. Pada penelitian ini bahan yang digunakan adalah 9 varietas padi yaitu Sarinah, Mutiara, Gendut, IR-64, PBBogor, Ciliwung, Ciherang, Kesit, dan Tewe. Setiap varietas dibagi menjadi 3 QTL yaitu sudut anakan, tinggi tanaman, dan jumlah bulir. Pupuk urea, SP-36, KCl, pestisida merek dagang Spontan, dan fungisida merek dagang Score. Dalam penelitian ini hanya 5 varietas padi yang akan dianalisis, yaitu dua varietas-QTL padi nasional (Ciherang dan Ciliwung) dan tiga varietas-QTL padi lokal (PB-Bogor, Kesit dan Tewe QTL).

Penelitian ini disusun berdasarkan RKTS (Rancangan Kelompok Teracak Sempurna). Masingmasing kelompok diambil 9 sampel tanaman yang dibagi menjadi 3 ulangan dan masing-masing ulangan 3 tanaman. Data pada masing-masing peubah diuji Bartlett dan Levene untuk kehomogenan ragam sebelum di analisis ragam. Bila uji $\mathrm{F}$ pada analisis ragam berbeda $\mathrm{P} \leq 0,05$ atau 0,01 dilakukan pemeringkatan varietas padi berdasarkan $\mathrm{BNJ}_{0,05}$. Besarnya ragam genetik dan heritabilitas broad-sense diduga berdasarkan nilai kuadrat nilai tengah harapan pada hasil analisis ragam.

Bibit padi berasal dari benih yang disemai terlebih dahulu. Tanah untuk persemaian diolah secara sempurna, bersih dari rumput, belukar, sisa-sisa tanaman, kayu, batu, atau lainnya. Benih disebar di persemaian dengan rapat, tetapi tidak bertumpukan. Lahan diolah menggunakan cangkul yang diolah secara sempurna. Pada pengolahan tanah sawah ini, dilakukan juga perbaikan dan pengaturan pematang sawah serta selokan. Setelah persiapan lahan beres maka bibit pun siap ditanam. Bibit dipindah tanam saat umur 21 hari. Ciri bibit yang siap dipindah ialah berdaun 2-4 helai. Bibit ditanam dengan posisi tegak dan dalam satu lubang ditanam masing-masing 2 bibit, dengan kedalaman tanam cukup $2 \mathrm{~cm}$ dengan jarak tanam padi $25 \times 25 \mathrm{~cm}$. Pemeliharaan tanaman berupa pemupukan, pengendalian hama dan penyakit, dan penyiangan gulma. Pupuk yang digunakan adalah urea $300 \mathrm{~kg} \mathrm{ha}^{-1}$ waktu aplikasi dibagi sebanyak tiga kali, SP-36 $100 \mathrm{~kg} \mathrm{ha}^{-1}$ diaplikasikan satu kali pada saat awal tanam, dan $\mathrm{KCl}$ $100 \mathrm{~kg} \mathrm{ha}^{-1}$ diaplikasikan dua kali pada saat awal tanam dan memasuki fase berbunga. Tanaman padi diseleksi berdasarkan tampilan segregasi fenotipe yang diduga QTL di antaranya jumlah anakan ditandai sampelnya menggunakan ajir bambu dengan cat berwarna merah, tinggi tanaman dan umur berbunga ditandai sampelnya menggunakan ajir bambu dengan cat berwarna biru.

\section{HASIL DAN PEMBAHASAN}

Pada Tabel 1 menunjukkan peringkat varietas berdasarkan $\mathrm{BNJ}_{0,05}$. Peringkat pertama menunjukkan varietas PB-Bogor adalah varietas terbaik daripada varietas yang lain. Kemudian berturut-turut diikuti oleh varietas Tewe, Ciherang, Kesit dan Ciliwung. Dapat

Tabel 1. Pemeringkatan varietas berdasarkan $\mathrm{BNJ}_{0,05}$.

\begin{tabular}{|c|c|c|c|c|c|c|}
\hline Varietas & $\begin{array}{l}\text { Jumlah } \\
\text { anakan total }\end{array}$ & $\begin{array}{l}\text { Tinggi } \\
\text { tanaman }\end{array}$ & $\begin{array}{l}\text { Bobot kering } \\
\text { malai }\end{array}$ & $\begin{array}{l}\text { Bobot } \\
\text { gabah isi }\end{array}$ & $\begin{array}{l}\text { Bobot gabah } \\
\text { hampa }\end{array}$ & $\begin{array}{l}\text { Bobot gabah } \\
\text { total }\end{array}$ \\
\hline PB-Bogor & 27,22 & 132,19 & $7,54 \mathrm{a}$ & 81,63 a & $12,36 \mathrm{a}$ & 93,99 a \\
\hline Ciliwung & $29,66 \mathrm{a}$ & 121,11 & 6,67 & 52,21 & $11,93 \mathrm{a}$ & 64,14 \\
\hline Ciherang & $32,74 \mathrm{a}$ & 114,89 & $6,72 \mathrm{a}$ & 63,29 & $11,85 \mathrm{a}$ & 75,14 \\
\hline Kesit & $31,56 \mathrm{a}$ & 117,22 & $6,80 \mathrm{a}$ & 60,06 & 14,54 & 74,59 \\
\hline Tewe & 27,76 & $144,87 \mathrm{a}$ & $6,91 \mathrm{a}$ & 61,44 & 18,79 & 80,23 a \\
\hline $\mathrm{BNJ}_{0,05}$ & 3,129 & 7,752 & 0,862 & 13,107 & 5,262 & 16,043 \\
\hline Varietas & \multicolumn{2}{|c|}{ Bobot 100 biji isi } & umlah gabah isi & Produksi & Jumlah huruf a & Peringkat \\
\hline PB-Bogor & $2,77 \mathrm{a}$ & \multicolumn{2}{|c|}{$3358,2 \mathrm{a}$} & $10,45 \mathrm{a}$ & 7 & 1 \\
\hline Ciliwung & 2,5 & \multicolumn{2}{|c|}{2266,1} & 6,68 & 2 & 4 \\
\hline Ciherang & 2,61 & \multicolumn{2}{|c|}{2581,3} & 8,1 & 3 & 3 \\
\hline Kesit & $2,73 \mathrm{a}$ & \multicolumn{2}{|c|}{2556,7} & 7,69 & 3 & 3 \\
\hline Tewe & $2,68 \mathrm{a}$ & \multicolumn{2}{|c|}{$2765,0 \mathrm{a}$} & 7,87 & 5 & 2 \\
\hline $\mathrm{BNJ}_{0,05}$ & 0,137 & \multicolumn{2}{|c|}{726,97} & 1,676 & & \\
\hline
\end{tabular}


dilihat bahwa varietas lokal lebih baik daripada dua varietas nasional. Hal ini menunjukkan seleksi padi varietas nasional yang dilakukan di pulau jawa yang memiliki lahan subur mempunyai kelemahan karena bila didistribusikan keluar dari daerah pulau jawa umumnya memiliki kesuburan yang rendah dan $\mathrm{pH}$ bersifat asam.

Tabel 2 menunjukkan peringkat QTL berdasarkan $\mathrm{BNJ}_{0,05}$. Peringkat QTL terbaik ditunjukkan oleh QTL sudut anakan dan QTL jumlah bulir karena memiliki jumlah huruf a yang sama. Sedangkan QTL tinggi tanaman diperingkat kedua. Secara produksi, QTL jumlah bulir lebih baik dibandingkan QTL sudut anakan tetapi QTL jumlah bulir memiliki kelemahan yaitu lebih banyaknya gabah hampa. Tabel 3 menunjukkan peringkat varietas-QTL berdasarkan $\mathrm{BNJ}_{0,05}$. VarietasQTL PB-Bogor jumlah bulir dan PB-Bogor sudut anakan berada pada peringkat pertama, tetapi terdapat perbedaan untuk produksi. PB-Bogor jumlah bulir mempunyai produksi yang lebih tinggi dari PB-Bogor sudut anakan. Hal ini menunjukkan bahwa QTL mempengaruhi varietas. Seperti pada Tabel 2 bahwa QTL jumlah bulir mempunyai produksi lebih tinggi daripada QTL sudut anakan meskipun keduanya berada diperingkat pertama.

Ragam genetik $\left(\sigma^{2} \mathrm{~g}\right)$, heritabilitas broad sense $\left(\mathrm{h}^{2}{ }_{\mathrm{BS}}\right)$, dan koefisien keragaman genetik (KKG) untuk varietas ditunjukkan pada Tabel 4. Data yang diperoleh menunjukkan bahwa karakter vegetatif dan generatif yang mampu mendeteksi $\sigma^{2} \mathrm{~g}$ dan $\mathrm{h}^{2}{ }_{\mathrm{BS}}$ adalah semua peubah kecuali bobot gabah total. Ragam genetik, herittabilitas broad sense, dan koefisien keragaman genetik (KKG) untuk QTL ditunjukkan pada Tabel 5. Data yang diperoleh menunjukkan bahwa karakter vegetatif dan generatif yang mampu mendeteksi ragam genetik dan heritabilitas broad sense adalah semua

Tabel 2. Peringkat QTL berdasarkan $\mathrm{BNJ}_{0.05}$.

\begin{tabular}{|c|c|c|c|c|c|c|}
\hline QTL & $\begin{array}{c}\text { Jumlah } \\
\text { anakan total }\end{array}$ & $\begin{array}{r}\text { Tinggi } \\
\text { tanaman }\end{array}$ & $\begin{array}{c}\text { Bobot } \\
\text { kering malai }\end{array}$ & $\begin{array}{c}\text { Bobot } \\
\text { gabah isi }\end{array}$ & $\begin{array}{c}\text { Bobot } \\
\text { gabah hampa }\end{array}$ & $\begin{array}{c}\text { Bobot } \\
\text { gabah total }\end{array}$ \\
\hline Sudut anakan & $30,05 \mathrm{a}$ & $127,17 \mathrm{a}$ & $6,66 \mathrm{a}$ & $61,27 \mathrm{a}$ & $12,41 \mathrm{a}$ & 73,67 \\
\hline Tinggi tanaman & 29,68 a & $123,00 \mathrm{a}$ & $6,90 \mathrm{a}$ & 60,49 & 12,37 & 73,87 \\
\hline Jumlah bulir & $30,62 \mathrm{a}$ & $128,00 \mathrm{a}$ & $7,22 \mathrm{a}$ & $69,41 \mathrm{a}$ & 15,99 & $85,32 \mathrm{a}$ \\
\hline $\mathrm{BNJ}_{0,05}$ & 2,068 & 5,099 & 0,567 & 8,622 & 3,462 & 10,55 \\
\hline QTL & Bobot 100 biji isi & \multicolumn{2}{|c|}{ Jumlah gabah isi } & Produksi & Jumlah huruf a & Peringkat \\
\hline Sudut anakan & $2,68 \mathrm{a}$ & \multicolumn{2}{|c|}{$2555,9 \mathrm{a}$} & $7,84 \mathrm{a}$ & 8 & 1 \\
\hline Tinggi tanaman & 2,58 & \multicolumn{2}{|c|}{$2693,7 \mathrm{a}$} & 7,74 & 4 & 3 \\
\hline Jumlah bulir & $2,71 \mathrm{a}$ & \multicolumn{2}{|c|}{$2866,8 \mathrm{a}$} & $8,87 \mathrm{a}$ & 8 & 1 \\
\hline $\mathrm{BNJ}_{0,05}$ & 0,09 & \multicolumn{2}{|l|}{478,22} & \multicolumn{2}{|l|}{1,103} & \\
\hline
\end{tabular}

peubah kecuali jumlah anakan total dan bobot gabah total. Sedangkan untuk varietas-QTL pada Tabel 6 menunjukkan bahwa semua karakter vegetatif dan generatif mampu mendeteksi ragam genetik dan heritabilitas broad sense. Ragam genetik merupakan nilai penduga besarnya keragaman genetik yang terdapat dalam populasi tanaman 15 varietas-QTL padi. Semakin besar keragaman genetik dalam suatu populasi tanaman maka semakin mudah untuk dilakukan seleksi genotipegenotipe yang diinginkan. Keragaman genetik yang tinggi karena $\geq 2 \mathrm{~GB}$ ragam genetik. Hasil penelitian Li et al. (2000 dalam Perwira 2004), perbedaan morfologi dan perbedaan genetik dapat terjadi akibat segregasi. Tanaman yang memiliki gen heterozigot pada salah satu lokusnya akan menyebabkan fenotipe yang berbeda. Adanya dominansi dan interaksi antargen juga menyebabkan keragaman dalam populasi. Secara genetik ini yang menyebabkan keragaman pada populasi bersegregasi.

Menurut Mangoendidjojo (2003), heritabilitas merupakan perbandingan atau proporsi varian genetik terhadap varian total (varian fenotipe). Heritabilitas tinggi menunjukkan bahwa faktor genetik lebih besar dibandingkan faktor lingkungan. Kriteria heritabilitas menurut Mangoendidjojo (2003), tanaman yang memiliki heritabilitas tinggi jika $\mathrm{h}^{2}{ }_{\mathrm{BS}}>50$, sedang jika terletak antara 20-50, dan rendah jika $\mathrm{h}^{2}{ }_{\mathrm{BS}}<20$. Pada Tabel 4 memperlihatkan bahwa setiap peubah menunjukkan heritabilitas yang tinggi kecuali peubah bobot gabah total.

Pada Tabel 5 memperlihatkan bahwa peubah tinggi tanaman, bobot kering malai, bobot gabah isi, bobot gabah hampa, bobot 100 gabah isi, dan produksi nyata menunjukkan heritabilitas yang tinggi. Untuk Tabel 6 menunjukkan bahwa seluruh peubah memiliki heritabilitas yang tinggi kecuali peubah bobot kering malai karena menunjukkan heritabilitas sedang. 
Tabel 3. Peringkat varietas-QTL berdasarkan $\mathrm{BNJ}_{0.05}$.

\begin{tabular}{|c|c|c|c|c|c|c|}
\hline Varietas-QTL & $\begin{array}{c}\text { Jumlah anakan } \\
\text { total }\end{array}$ & $\begin{array}{c}\text { Tinggi } \\
\text { tanaman }\end{array}$ & $\begin{array}{c}\text { Bobot kering } \\
\text { malai }\end{array}$ & \multicolumn{2}{|c|}{$\begin{array}{l}\text { Bobot gabah } \\
\text { isi }\end{array}$} & $\begin{array}{c}\text { Bobot gabah } \\
\text { hampa }\end{array}$ \\
\hline Pbbsud & 27,55 & $133,33 \mathrm{a}$ & $7,09 \mathrm{a}$ & \multicolumn{2}{|c|}{$77,56 \mathrm{a}$} & $10,77 \mathrm{a}$ \\
\hline Pbbtgi & 25,22 & $131,11 \mathrm{a}$ & $7,81 \mathrm{a}$ & \multicolumn{2}{|c|}{64,39} & 14,26 \\
\hline Pbbjbu & 28,89 a & $132,11 \mathrm{a}$ & $7,71 \mathrm{a}$ & \multicolumn{2}{|c|}{$102,94 \mathrm{a}$} & 12,06 \\
\hline Cilsud & $30,66 \mathrm{a}$ & 104,11 & $6,78 \mathrm{a}$ & \multicolumn{2}{|c|}{42,11} & 15,02 \\
\hline Ciltgi & $29,22 \mathrm{a}$ & 106,44 & $6,51 \mathrm{a}$ & \multicolumn{2}{|c|}{58,44} & 9,88 a \\
\hline Ciljbu & $29,11 \mathrm{a}$ & 121,78 & $6,71 \mathrm{a}$ & \multicolumn{2}{|c|}{56,08} & $10,89 \mathrm{a}$ \\
\hline Cihsud & $33,11 \mathrm{a}$ & $135,11 \mathrm{a}$ & $6,43 \mathrm{a}$ & \multicolumn{2}{|c|}{72,34} & 9,08 a \\
\hline Cihtgi & $31,22 \mathrm{a}$ & 123,56 & $6,78 \mathrm{a}$ & \multicolumn{2}{|c|}{48,58} & 13,78 \\
\hline Cihjbu & 33,89 a & 117,00 & $6,94 \mathrm{a}$ & \multicolumn{2}{|c|}{68,94} & 12,69 \\
\hline Kessud & 29,44 a & 106,56 & $6,57 \mathrm{a}$ & \multicolumn{2}{|c|}{63,64} & $10,61 \mathrm{a}$ \\
\hline Kestgi & 34,67 a & 106,22 & 6,51 & \multicolumn{2}{|c|}{70,18} & 23,57 \\
\hline Kesjbu & $30,56 \mathrm{a}$ & $138,89 \mathrm{a}$ & $7,32 \mathrm{a}$ & \multicolumn{2}{|c|}{46,34} & 23,57 \\
\hline Tewsud & $29,50 \mathrm{a}$ & $143,83 \mathrm{a}$ & $6,43 \mathrm{a}$ & \multicolumn{2}{|c|}{50,68} & 16,54 \\
\hline Tewtgi & $28,11 \mathrm{a}$ & $147,67 \mathrm{a}$ & $6,91 \mathrm{a}$ & \multirow{2}{*}{\multicolumn{2}{|c|}{$\begin{array}{l}60,87 \\
72,77\end{array}$}} & 19,54 \\
\hline Tewjbu & 25,67 & $143,11 \mathrm{a}$ & $7,40 \mathrm{a}$ & & & 20,29 \\
\hline $\mathrm{BNJ}_{0,05}$ & 6,895 & 17,082 & 1,901 & \multicolumn{2}{|c|}{28,881} & 11,595 \\
\hline Varietas-QTL & $\begin{array}{c}\text { Bobot gabah } \\
\text { total }\end{array}$ & $\begin{array}{c}\text { Bobot } 100 \\
\text { biji isi }\end{array}$ & $\begin{array}{l}\text { Jumlah } \\
\text { gabah isi }\end{array}$ & Produksi & $\begin{array}{l}\text { Jumlah } \\
\text { huruf a }\end{array}$ & Peringkat \\
\hline Pbbsud & 88,33 a & $2,73 \mathrm{a}$ & $3113,6 \mathrm{a}$ & $9,97 \mathrm{a}$ & 8 & 1 \\
\hline Pbbtgi & 78,65 & $2,69 \mathrm{a}$ & 2902,6 & 8,24 & 3 & 5 \\
\hline Pbbjbu & $115,01 \mathrm{a}$ & $2,88 \mathrm{a}$ & $4058,4 \mathrm{a}$ & $13,18 \mathrm{a}$ & 8 & 1 \\
\hline Cilsud & 57,13 & 2,54 & 2149,1 & 5,39 & 2 & 7 \\
\hline Ciltgi & 68,31 & 2,46 & 2340,8 & 7,48 & 3 & 6 \\
\hline Ciljbu & 66,97 & 2,51 & 2308,6 & 7,18 & 3 & 6 \\
\hline Cihsud & $81,42 \mathrm{a}$ & $2,69 \mathrm{a}$ & $2878,7 \mathrm{a}$ & 9,26 & 7 & 2 \\
\hline Cihtgi & 62,37 & 2,51 & 2105,7 & 6,22 & 2 & 7 \\
\hline Cihjbu & 81,63 a & $2,63 \mathrm{a}$ & 2759,4 & 8,83 & 4 & 5 \\
\hline Kessud & 74,26 & $2,79 \mathrm{a}$ & 2271,2 & 8,15 & 4 & 5 \\
\hline Kestgi & 79,61 & $2,61 \mathrm{a}$ & $3299,7 \mathrm{a}$ & 8,99 & 3 & 6 \\
\hline Kesjbu & 69,92 & $2,78 \mathrm{a}$ & 2099,2 & 5,93 & 4 & 5 \\
\hline Tewsud & 67,21 & $2,64 \mathrm{a}$ & 2366,8 & 6,49 & 4 & 5 \\
\hline Tewtgi & $80,41 \mathrm{a}$ & $2,64 \mathrm{a}$ & $2819,9 \mathrm{a}$ & 7,79 & 6 & 3 \\
\hline Tewjbu & $93,06 \mathrm{a}$ & $2,75 \mathrm{a}$ & $3108,3 \mathrm{a}$ & 9,32 & 5 & 4 \\
\hline $\mathrm{BNJ}_{0,05}$ & 35,351 & 0,303 & 1601,9 & 3,694 & & \\
\hline
\end{tabular}

Keterangan $:$ pbb = varietas PB-Bogor, cil = varietas ciliwung, $\mathrm{cih}=$ varietas ciherang, $\mathrm{kes}=\mathrm{varietas}$ kesit, tew $=$ varietas tewe. sud = QTL-sudut anakan, jbu = QTL-jumlah bulir, tgi = QTL-tinggi tanaman.

Keragaman di dalam populasi terhadap peubah pertumbuhan tanaman dapat diketahui dengan menghitung nilai keragaman genetik (KKg). Menurut Hikam (2010), pada KKg < 5\% menunjukkan bahwa pengaruh genetik lebih besar dari pengaruh lingkungan, seluruh tampilan fenotipik merupakan hasil kerja genetik dan pengaruh lingkungan dapat diabaikan. Nilai KKg yang baik pada kondisi ideal berkisar antara 5-10\%. Nilai $\mathrm{KKg} \leq 10 \%$ dianggap takbias yang berarti terpakainya kinerja fenotipe sebagai penduga genotipe dengan lingkungan tidak dapat diabaikan. Pada Tabel 7 menunjukkan hasil antar karakter peubah yang diuji dalam penelitian ini. Terdapat peubah baik vegetatif maupun generatif yang saling berkorelasi. Peubah yang berkorelasi ditunjukkan dengan simbol (*) pada Tabel 7. Pada Tabel 7 diperoleh korelasi nyata antara bobot kering malai dengan bobot gabah isi, bobot gabah hampa, bobot gabah total, bobot 100 biji isi, jumlah gabah isi, 
Tabel 4. Ragam genetik, heritabilitas broad-sense, koefisien keragaman genetik varietas untuk karakter vegetatif dan generatif.

\begin{tabular}{lcrc}
\hline \multicolumn{1}{c}{ Variabel } & $\sigma^{2} \mathrm{~g} \pm \mathrm{GB} \sigma^{2} \mathrm{~g}$ & $\mathrm{~h}^{2}{ }_{\mathrm{BS}} \pm \mathrm{GB} \mathrm{h}^{2}{ }_{\mathrm{BS}}(\%)$ & $\mathrm{KKg}(\%)$ \\
\hline Jumlah anakan total & $5,06 \pm 0,51^{* * *}$ & $89,775 \pm 9,082^{* *}$ & 7,55 \\
Tinggi tanaman & $151,15 \pm 14,03^{* *}$ & $97,712 \pm 9,073^{* *}$ & 9,75 \\
Bobot kering malai & $0,08 \pm 0,01^{* *}$ & $64,990 \pm 9,183^{* *}$ & 4,11 \\
Bobot gabah isi & $107,89 \pm 10,71^{* *}$ & $91,426 \pm 9,079^{* *}$ & 16,30 \\
Bobot gabah hampa & $7,06 \pm 0,79^{* * *}$ & $81,232 \pm 9,104^{* *}$ & 19,12 \\
Bobot gabah total & $-306,45 \pm 20,27$ & $-259,659 \pm 17,182$ & 0 \\
Bobot 100 biji isi & $0,01 \pm 0,001^{* *}$ & $89,850 \pm 9,082^{* *}$ & 3,72 \\
Jumlah gabah isi & $133906,0 \pm 15025,5^{* *}$ & $81,137 \pm 9,104^{* *}$ & 13,52 \\
Produksi & $1,76 \pm 0,17^{* *}$ & $91,430 \pm 9,079^{* *}$ & 16,28 \\
\hline
\end{tabular}

Keterangan: $\sigma^{2} \mathrm{~g}=$ ragam genetik, $\mathrm{GB} \sigma^{2} \mathrm{~g}=$ galat baku ragam genetik, $\mathrm{h}^{2}{ }_{\mathrm{BS}}=$ heritabilitas broad-sense, $\mathrm{GB}$ $\mathrm{h}^{2}{ }_{\mathrm{BS}}=$ galat baku heritabilitas broad-sense, $\mathrm{KKg}=$ koefisien keragaman genetik, " = berbeda dari nol $\left(\sigma^{2} \mathrm{~g}\right.$ atau $\left.\mathrm{h}^{2}{ }_{\mathrm{BS}} \geq 2 \mathrm{~GB}\right),{ }^{* *}=$ berbeda dari nol $\left(\sigma^{2} \mathrm{~g}\right.$ atau $\left.\mathrm{h}^{2}{ }_{\mathrm{BS}} \geq 2 \mathrm{~GB}\right)$.

Tabel 5. Ragam genetik, heritabilitas broad-sense, koefisien keragaman genetik QTL untuk karakter vegetatif dan generatif.

\begin{tabular}{lccc}
\hline \multicolumn{1}{c}{ Variabel } & $\sigma^{2} \mathrm{~g} \pm \mathrm{GB} \sigma^{2} \mathrm{~g}$ & $\mathrm{~h}^{2}{ }_{\mathrm{BS}} \pm \mathrm{GB} \mathrm{h}^{2}{ }_{\mathrm{BS}}(\%)$ & $\mathrm{KKg}(\%)$ \\
\hline Jumlah anakan total & $-0,292 \pm 0,01$ & $-536,93 \pm 16,87$ & 0 \\
Tinggi tanaman & $5,053 \pm 0,48^{* * *}$ & $70,40 \pm 6,70^{* * *}$ & 1,78 \\
Bobot kering malai & $0,052 \pm 0,00^{* * *}$ & $66,23 \pm 6,71^{* * *}$ & 3,27 \\
Bobot gabah isi & $18,370 \pm 1,63^{* * *}$ & $75,16 \pm 6,69^{* * *}$ & 6,72 \\
Bobot gabah hampa & $2,27 \pm 0,21^{* * *}$ & $69,90 \pm 6,70^{* * *}$ & 10,85 \\
Bobot gabah total & $-165,78 \pm 8,57^{* * *}$ & $-186,46 \pm 9,64$ & 0 \\
Bobot 100 biji isi & $0,004 \pm 0,00^{* *}$ & $85,30 \pm 6,67^{* *}$ & 2,33 \\
Jumlah gabah isi & $5592,0 \pm 1680,67^{* *}$ & $23,04 \pm 6,92^{* *}$ & 2,76 \\
Produksi & $0,30 \pm 0,03^{* * *}$ & $75,18 \pm 6,69^{* * *}$ & 6,72 \\
\hline
\end{tabular}

Keterangan: $\sigma^{2} \mathrm{~g}=$ ragam genetik, $\mathrm{GB} \sigma^{2} \mathrm{~g}=$ galat baku ragam genetik, $\mathrm{h}^{2}{ }_{\mathrm{BS}}=$ heritabilitas broad-sense, $\mathrm{GB}$ $\mathrm{h}^{2}{ }_{\mathrm{BS}}=$ galat baku heritabilitas broad-sense, $\mathrm{KKg}=$ koefisien keragaman genetik, * = berbeda dari nol $\left(\sigma^{2} \mathrm{~g}\right.$ atau $\left.\mathrm{h}^{2}{ }_{\mathrm{BS}} \geq 2 \mathrm{~GB}\right),{ }^{* *}=$ berbeda dari nol $\left(\sigma^{2} \mathrm{~g}\right.$ atau $\left.\mathrm{h}^{2}{ }_{\mathrm{BS}} \geq 2 \mathrm{~GB}\right)$.

Tabel 6. Ragam genetik, heritabilitas broad-sense, koefisien keragaman genetik varietas-QTL untuk karakter vegetatif dan generatif.

\begin{tabular}{lccc}
\hline \multicolumn{1}{c}{ Variabel } & $\sigma^{2} \mathrm{~g} \pm \mathrm{GB} \mathrm{\sigma ^{2 } \mathrm { g }}$ & $\mathrm{h}^{2}{ }_{\mathrm{BS}} \pm \mathrm{GB} \mathrm{h}^{2}{ }_{\mathrm{BS}}(\%)$ & $\mathrm{KKg}(\%)$ \\
\hline Jumlah anakan total & $5,95 \pm 1,24^{* *}$ & $76,38 \pm 16,91^{* *}$ & 7,94 \\
Tinggi tanaman & $216,69 \pm 37,91^{* *}$ & $95,33 \pm 16,68^{* *}$ & 11,68 \\
Bobot kering malai & $0,07 \pm 0,04^{*}$ & $35,56 \pm 18,42^{*}$ & 3,89 \\
Bobot gabah isi & $199,51 \pm 38,49^{* *}$ & $86,79 \pm 16,74^{* *}$ & 22,17 \\
Bobot gabah hampa & $14,29 \pm 3,25^{* *}$ & $74,49 \pm 16,95^{* *}$ & 27,21 \\
Bobot gabah total & $156,40 \pm 34,10^{* *}$ & $77,48 \pm 16,89^{* *}$ & 16,11 \\
Bobot 100 biji isi & $0,14 \pm 0,02^{* *}$ & $97,66 \pm 16,67^{* *}$ & 14,03 \\
Jumlah gabah isi & $208600,00 \pm 51599,5^{* *}$ & $69,08 \pm 17,09^{* *}$ & 16,88 \\
Produksi & $3,27 \pm 0,63^{* *}$ & $86,81 \pm 16,74^{* *}$ & 22,15 \\
\hline
\end{tabular}

Keterangan: $\sigma^{2} \mathrm{~g}=$ ragam genetik, $\mathrm{GB} \sigma^{2} \mathrm{~g}=$ galat baku ragam genetik, $\mathrm{h}^{2}{ }_{\mathrm{BS}}=$ heritabilitas broad-sense, $\mathrm{GB}$ $\mathrm{h}^{2}{ }_{\mathrm{BS}}=$ galat baku heritabilitas broad-sense, $\mathrm{KKg}=$ koefisien keragaman genetik, ${ }^{*}=$ berbeda dari nol $\left(\sigma^{2} \mathrm{~g}\right.$ atau $\left.\mathrm{h}^{2}{ }_{\mathrm{BS}} \geq 2 \mathrm{~GB}\right),{ }^{* *}=$ berbeda dari nol $\left(\sigma^{2} \mathrm{~g}\right.$ atau $\left.\mathrm{h}^{2}{ }_{\mathrm{BS}} \geq 2 \mathrm{~GB}\right)$. 
Tabel 7. Korelasi untuk karakter vegetatif dan generatif.

\begin{tabular}{|c|c|c|c|c|c|}
\hline Variabel & $\begin{array}{l}\text { Jumlah } \\
\text { anakan total }\end{array}$ & $\begin{array}{l}\text { Tinggi } \\
\text { tanaman }\end{array}$ & $\begin{array}{l}\text { Bobot kering } \\
\text { malai }\end{array}$ & $\begin{array}{l}\text { Bobot } \\
\text { gabah isi }\end{array}$ & $\begin{array}{l}\text { Bobot gabah } \\
\text { hampa }\end{array}$ \\
\hline Tinggi tanaman & $-0,504 * *$ & & & & \\
\hline Bobot kering malai & $-0,168$ & $0,372 *$ & & & \\
\hline Bobot gabah isi & 0,033 & $-0,059$ & $0,502 * *$ & & \\
\hline Bobot gabah hampa & $-0,092$ & $0,634 * *$ & $0,496 * *$ & $-0,14$ & \\
\hline Bobot gabah total & 0,004 & 0,141 & $0,655 * *$ & $0,950 * *$ & 0,175 \\
\hline Bobot 100 biji isi & $-0,225$ & 0,265 & $0,338 *$ & $0,467 * *$ & 0,23 \\
\hline Jumlah benih isi & 0,089 & 0,102 & $0,555 * *$ & $0,892 * *$ & 0,006 \\
\hline Produksi ip 400 & 0,033 & $-0,058$ & $0,502 * *$ & $1,000 * *$ & $-0,14$ \\
\hline Produksi nyata & 0,034 & $-0,059$ & $0,502 * *$ & $1,000 * *$ & $-0,14$ \\
\hline Variabel & \multicolumn{2}{|c|}{ Bobot gabah total } & 0 biji isi & Jumlah gabah isi & Produksi ip 400 \\
\hline \multicolumn{6}{|l|}{ Bobot gabah total } \\
\hline Bobot 100 biji isi & \multicolumn{2}{|l|}{$0,537 * *$} & & & \\
\hline Jumlah benih isi & $0,889 * *$ & \multicolumn{2}{|c|}{$0,370^{*}$} & & \\
\hline Produksi ip 400 & $0,950 * *$ & \multicolumn{2}{|c|}{$0,467 * *$} & $0,892 * *$ & \\
\hline Produksi nyata & $0,950 * *$ & \multicolumn{2}{|c|}{$0,467 * *$} & $0,892 * *$ & $1,000 * *$ \\
\hline
\end{tabular}

Keterangan: Korelasi antar peubah nyata pada $*=\alpha_{0,01}, * *=\alpha_{0,05}$.

produksi ip 400 dan produksi nyata. Peubah yang memiliki korelasi nyata terhadap peubah yang menggambarkan produksi yaitu bobot gabah isi. Peubah yang berkorelasi dengan bobot gabah isi adalah bobot gabah total, bobot 100 biji isi, jumlah gabah isi, produksi ip 400 dan produksi nyata. Peubah yang berkorelasi nyata terhadap peubah produksi dapat dijadikan kriteria seleksi selanjutnya (seleksi tidak langsung).

Menurut Wahyuni (2010) suatu karakter dapat digunakan sebagai kriteria seleksi apabila memenuhi prasyarat, yaitu terdapat hubungan yang nyata antara karakter tersebut dengan karakter yang dituju dan karakter tersebut memiliki heritabilitas yang cukup tinggi sehingga dapat diwariskan pada keturunannya. Hasil penelitian Puri et al. (1982) menunjukkan bahwa tanaman barley yang mampu berproduksi tinggi dapat diperoleh dengan menyeleksi tanaman yang memiliki bobot biji dan bobot biji/ malainya tinggi karena menunjukkan korelasi yang positif dengan produksi. Hasil penelitian Rakhmah (2000) mengatakan bahwa produksi padi dapat ditingkatkan dengan menyeleksi tanaman yang memiliki tinggi yang rendah.

\section{KESIMPULAN}

Kesimpulan penelitian ini adalah QTL pada tanaman padi muncul pada varietas nasional dan lokal di lingkungan sawah baru, yaitu QTL sudut anakan, QTL tinggi tanaman dan QTL jumlah bulir. Semua peubah pengamatan mampu memberikan perbedaan ragam genetik dan heritabilitas broad-sense. Varietas peubah bobot gabah total tidak memberikan perbedaan, begitu juga pada QTL peubah jumlah anakan total dan bobot gabah total yang tidak memberikan perbedaan ragam genetik dan heritabilitas broad-sense. Peubah yang dapat dijadikan seleksi tidak langsung adalah jumlah gabah isi.

\section{DAFTAR PUSTAKA}

Hikam, S. 2010. Teknik Perancangan dan Analisis Pemuliaan Tanaman. Fakultas Pertanian Universitas Lampung. Bandarlampung. Dalam penerbitan. $31 \mathrm{hlm}$.

Mangoendidjojo, W. 2003. Dasar-Dasar Pemuliaan Tanaman. Kanisius. Yogyakarta. $182 \mathrm{hlm}$.

Nafisah, A. A. Darajat, dan H. Sembiring. 2008. Keragaman Genetik Padi dan Upaya Pemanfaatannya dalam Mendukung Ketahanan Pangan Nasional. Lokakarya Nasional Pengelolaan dan Perlindungan Sumber Daya Genetik di Indonesia. 63-73 hlm.

Perwira, A. D. 2004. Keragaan Karakter Agronomi Generasi F3 Enam Persilangan Padi Gogo. Skripsi. Institut Pertanian Bogor. 1-10 hlm. 
Puri, Y.P., C.O. Qualset, dan W.A. Williams. 1982. Evaluation of Yield Components as Selection Criteria in Barley Breeding. Crop Sci. 22:931937.

Rakhmah, A. 2000. Studi Pertumbuhan, Daya Hasil dan Viabilitas Benih Tanaman Utama dan Ratoon dari 19 Genotipe Padi Gogo Asal Kalimantan Timur. Skripsi. Institut Pertanian bogor. Bogor. $44 \mathrm{hlm}$.
Suprayogi, L. 2011. Evaluasi Plasma Nutfah Padi yang Tersegregasi Transgresif sebagai Tetua Inbred pada Perakitan Padi Hibrida dan Inbrida. Skripsi. Universitas Lampung. Bandar Lampung. 1-13 hlm.

Wahyuni, A. 2010. Seleksi Masa Lima Ras Lokal Lampung Tanaman Cabai Merah Keriting Organik dengan Penapisan Dolomit. Skripsi. Universitas Lampung. Bandar Lampung. $61 \mathrm{hlm}$. 